\title{
Methylation-GC-MS analysis of arabinofuranose- and galactofuranose-containing structures: rapid synthesis of partially $O$-methylated alditol acetate standards
}

\author{
GUILHERME L. SASSAKI, MARCELLO IACOMINI and PHILIP A.J. GORIN \\ Departamento de Bioquímica e Biologia Molecular, Universidade Federal do Paraná \\ Cx. Postal 19046, 81531-990 Curitiba, PR, Brasil \\ Manuscript received on December 12, 2004; accepted for publication on February 24, 2005; \\ contributed by PHILIP A.J. GORIN*
}

\begin{abstract}
Arabinose and galactose were treated with $\mathrm{MeOH}$ containing traces of $\mathrm{H}_{2} \mathrm{SO}_{4}$ or $\mathrm{HCl}$ at $25^{\circ} \mathrm{C}$ to give mixtures of their methyl alpha- and beta-furanosides, as shown by 1D and 2D nuclear magnetic resonance (NMR). Oxidation of the Me alpha,beta-Ara $f$ mixture with $\mathrm{NaIO}_{4}$ preferentially oxidised the beta-isomer, to give pure Me alpha-Ara $f$. Each product was progressively $O$-methylated using the Purdie reagent $\left(\mathrm{MeI} / \mathrm{Ag}_{2} \mathrm{O}\right)$ at $25^{\circ} \mathrm{C}$ and resulting mixtures of partially methylated glycosides (PMGs) were rapidly assayed by thin layer chromatography (TLC) first to favour higher yields of mono- $O$-methyl derivatives and later for products with higher degrees of methylation. The products were converted to complex mixtures of partially $O$-methylated alditol acetate derivatives (PMAAs) by successive hydrolysis, reduction with $\mathrm{NaBD}_{4}$, and acetylation. These can be used as gas chromatography-mass spectrometry (GC-MS) standards in methylation analysis of complex carbohydrates containing arabinofuranosyl and galactofuranosyl units. Of particular interest were the retention times and electron impact MS of the difficult to prepare alditol acetates of 5,6- $\mathrm{Me}_{2} \mathrm{Gal}, 2,5-\mathrm{Me}_{2} \mathrm{Gal}$, 2,5,6- $\mathrm{Me}_{3} \mathrm{Gal}, 3,5,6-\mathrm{Me}_{3} \mathrm{Gal}, 5-\mathrm{MeAra}, 2,5-\mathrm{Me}_{2} \mathrm{Ara}$, and 3,5- $\mathrm{Me}_{2} \mathrm{Ara}$. The relative reactivities of hydroxyl groups for mixtures of Me alpha- and Me beta-Gal $f$ were $\mathrm{HO}-2>\mathrm{HO}-3>\mathrm{HO}-6>\mathrm{HO}-5$, that of Me alphaand Me beta-Ara $f$ HO-2 $>$ HO-3 $>$ HO-5, and that of Me alpha-Ara $f$ HO-2 $>\mathrm{HO}-3 \geq \mathrm{HO}-5$.
\end{abstract}

Key words: partially $O$-methylated alditol acetates, GC-MS standards, Purdie methylation, OH reactivity, NMR.

\section{INTRODUCTION}

Arabinose and galactose are widely found in complex carbohydrates and are present in pyranosyl and furanosyl rings in molecules encompassing a great variety of glycosidic linkages with $\alpha$ - and $\beta$ anomeric configurations. Units of $\operatorname{Ara} f$ are found in polysaccharides of plants, as in gums and free or protein-linked arabinogalactans: to the latter

* Member Academia Brasileira de Ciências

Correspondence to: Philip A.J. Gorin

E-mail: cesarat@ufpr.br many functions have been assigned, including plant growth and development, as well as cell proliferation, expansion and death (Svetek et al. 1999). On the other hand, galactofuranosyl-containing molecules do not occur in green plants, but are widespread in glycolipids, proteoglycans, cell-wall polysaccharides, and exopolysaccharides (EPS) of fungi and yeasts (Barreto-Bergter and Gorin 1983, Levery et al. 1998, Sassaki et al. 2002, Jones et al. 2004). Gal $f$ units are also present in macromolecules of bacteria and protozoans, but not in mammals, which 
are highly immunogenic to them. The Gal $f$ containing molecules of bacteria, protozoans, and fungi appear to play different roles, but their influence in the recognition and/or invasion parasitehost have been observed (Suzuki et al. 1997, Levery et al. 1998), probably by their $\beta$-Gal $f$-containing epitopes.

Methylation analysis of complex sugars provides information on the substitution position of their glycosidic linkages. In this procedure the molecule can be first completely $O$-methylated by the methods of Haworth 1915, Kuhn et al. 1955, and Hakomori 1964, but nowadays the most used frequently in our hands is that of Ciucanu and Kerek 1984. The products can be converted by successive hydrolysis to give partially $O$-methylated aldoses, which are reduced with $\mathrm{NaBH}_{4}$, followed by acetylation to provide partially $O$-methylated alditol acetates (PMAAs), which on GC-MS, have typical retention times $\left(R_{t}\right)$ and electron impact (e.i.) spectra (Jansson et al. 1970). Sometimes, the product suffers from a symmetry problem, for example 2,3di- $O$ - $=3,4$-di- $O$-methylxylitol acetate, but this can be overcome by reduction with $\mathrm{NaBD}_{4}$, which introduces deuterium at C-1 (Carpita and Shea 1989).

For the preparation of PMAA standards, there is an option of preparing each one individually or all at once by partial $O$-methylation of methyl aldosides. For the latter experiment, Haworth $\left(\mathrm{Me}_{2} \mathrm{SO}_{4} /\right.$ $\mathrm{NaOH}$ ), Purdie $\left(\mathrm{MeI} / \mathrm{Ag}_{2} \mathrm{O}\right)$, Kuhn (MeI/DMF/ $\mathrm{Ag}_{2} \mathrm{O}$ ), and Hakomori (MeI/methylsulfinylmethanide/ $\mathrm{Me}_{2} \mathrm{SO}$ ) methylations have been carried out. The methylation of methyl $\alpha$-mannopyranoside was performed out by Handa and Montgomery (1969), using the Haworth, Kuhn, and Hakomori procedures, and by Fournet and Montreuil (1973) with the Kuhn methylation, which formed all possible $O$-methyl derivatives, except for the mono- $O$ methyl ones. This was rectified by Fournet et al. (1974) who prepared and converted them to their mono- $O$-methyl alditol acetates, which were examined by GC-MS, sodium borodeuteride being used in the intermediate reduction step. A similar procedure was used for preparation of $15 O$-methyl alditol acetates starting from methyl $\alpha$-galactopyranoside (Fournet et al. 1978) and the MS data were presented in a tabular form.

Another of the early investigations directed to the preparation of methylation standards for carbohydrate analysis was by Elkin et al. (1975), who partially and fully $O$-methylated the methyl pyranosides of Rha, Fuc, Ara, Xyl, Man, Gal, and Glc, among others with the Purdie reagent (Purdie and Irvine 1903), but the resulting $O$-methyl derivatives were only poorly resolved by GLC and MS and not employed.

Although they did not contain the synthesis of PMAAs, the classic publications of Jansson et al. (1970) and Carpita and Shea (1989) contained the retention times $\left(R_{t}\right.$ 's) and e.i. profiles on GC-MS, with few exceptions, of those that can arise from pyranosyl and furanosyl structures.

Lomax and Conchie (1982) used the Purdie reagent to partially and fully methylate the same methyl pyranosides and converted them to PMAAs, which were subjected to GC and although MS was mentioned, no details were included. Methyl arabinofuranoside but not methyl galactofuranoside were investigated.

Doares et al. (1991) carried out partial to complete methylation of methyl pyranosides of Rha, Fuc, Ara, Xyl, Man, Gal, and Glc with potassium methylsulphinylmethanide in $\mathrm{Me}_{2} \mathrm{SO} / \mathrm{MeI}$ to form PMGs. Their $R_{t}$ s of resulting PMAAs, formed using an intermediate sodium borodeuteride reduction, were recorded and identification was accomplished by referring to the e.i. profiles of Carpita and Shea (1989). A study incorporating synthesis of partially to fully $O$-methylated PMG derivatives from the same methyl pyranosides, followed by their conversion to all possible PMAAs, with the exception of the 6- $O$-methyl derivative, and determination of their $R_{t} \mathrm{~s}$ and e.i. breakdown profiles, was carried out by Sassaki et al. (2005) using the relatively easy to handle Purdie reagent.

The same approach has now been extended to the furanoside series, starting from synthesised methyl arabinofuranosides and methyl galactofura- 
nosides, to finally form all the PMAAs necessary for GC-MS analysis of arabinofuranose- and galactofuranose-containing structures.

\section{MATERIALS AND METHODS}

\section{Preparation of Methyl Glycofuranosides}

Galactose and arabinose were obtained from Sigma-Aldrich, MO, U.S.A and each $(500 \mathrm{mg})$ was stirred in $0.5 \% \mathrm{w} / \mathrm{w} \mathrm{MeOH}-\mathrm{HCl}(100 \mathrm{ml})$ or $0.5 \% \mathrm{w} / \mathrm{w} \mathrm{MeOH}-\mathrm{H}_{2} \mathrm{SO}_{4}(100 \mathrm{ml})$ at $25^{\circ} \mathrm{C}$ until complete dissolution (for Ara: $6 \mathrm{~h}$, for Gal: $16 \mathrm{~h}$ ). The solution was neutralised with excess pyridine, evaporated to a small volume, and acetylated with $\mathrm{Ac}_{2} \mathrm{O}$-pyridine $(2 \mathrm{ml} ; 1: 1, \mathrm{v} / \mathrm{v})$ overnight at room temperature. The mixture was added to excess icewater and after $1 \mathrm{~h}$, it was extracted with $\mathrm{CHCl}_{3}$, which was evaporated to dryness. The residue was dissolved in $\mathrm{MeOH}$ containing $\mathrm{NaOMe}(5 \mathrm{ml}$, $200 \mathrm{mM}$ ) and after $2 \mathrm{~h}$, the solution was evaporated to dryness, and then treated with an aq. suspension of Dowex 50W-X8 $\mathrm{H}^{+}$, providing after evaporation Me $\alpha \beta$-Ara $f$ or Me $\alpha \beta$-Gal $f$.

$\operatorname{Me} \alpha \beta$-Ara $f(113 \mathrm{mg})$ with treated with 2 molar equivalents of $\mathrm{NaIO}_{4}(295 \mathrm{mg})$ in $\mathrm{H}_{2} \mathrm{O}(10 \mathrm{ml})$ for $30 \mathrm{~min}$ at $25^{\circ} \mathrm{C}$. The solution was treated with a mixture of Amberlite IR-120 $\left(\mathrm{H}^{+}\right)$and IR-400 $\left(\mathrm{OH}^{-}\right)$, the latter to remove dialdehyde, the suspension filtered, and the filtrate freeze dried to give $\operatorname{Me} \alpha$-Ara $f$ (19 mg).

\section{NMR Analysis of Methyl Arabinoside and Methyl Galactofuranoside Preparations}

Each methyl glycofuranoside preparation was deuterium exchanged by repeated $\mathrm{D}_{2} \mathrm{O}$ dissolution, followed by evaporation. $1 \mathrm{D}$ and $2 \mathrm{D}{ }^{1} \mathrm{H}$ and coupled and decoupled ${ }^{13} \mathrm{C}$ NMR spectra were obtained using a Bruker Avance DRX-400 spectrometer with a $5 \mathrm{~mm}$ inverse probe. ${ }^{13} \mathrm{C}-\mathrm{NMR}$ acquisitions were performed using the following parameters: FIDRES- $0.8466 \mathrm{~Hz}$, AQ- $0.5906 \mathrm{~s}$, DW $15.75 \mathrm{~s}$, DE- $5.5 \mu \mathrm{s}$ D1- $110 \mathrm{msec}$, D2- $3.4 \mathrm{msec}$, PL12-17dB (decoupler ${ }^{1} \mathrm{H}$ ), waltz 16 pulse program. Coupled ${ }^{13} \mathrm{C}$ NMR spectrum was obtained under similar con- ditions using PL12 of $60 \mathrm{db}$. The spectra were obtained in $\mathrm{D}_{2} \mathrm{O}$ either at $30^{\circ} \mathrm{C}$ or $70^{\circ} \mathrm{C}$, and chemical shifts measured in relation to $\mathrm{Me}_{4} \mathrm{Si}(\delta=0)$.

Purdie Methylation of Methyl GlycofuraNOSIDES

Each glycoside (10 mg) was submitted to vigorous stirring in $\mathrm{MeI}(1.5 \mathrm{ml})$, containing $\mathrm{Ag}_{2} \mathrm{O}(250 \mathrm{mg})$ at room temperature over a period of $2 \mathrm{~h}$. Each one gradually dissolved in the suspension and the degree of methylation was monitored at $30 \mathrm{~min}$ intervals using aliquots, which were removed and spotted on to TLC plates (solvent: $\mathrm{CHCl}_{3}-\mathrm{EtOH}, 9: 1 \mathrm{v} / \mathrm{v}$ ), developed with orcinol- $\mathrm{H}_{2} \mathrm{SO}_{4}$ spray $-100^{\circ} \mathrm{C}$ for 5 min (Skipiski 1975), and the spot intensities measured by Scion Imaging.

\section{PREPARATION OF PMAAs}

PMG mixtures were evaporated to dryness and the residue was hydrolysed with $\mathrm{M} \mathrm{H}_{2} \mathrm{SO}_{4}$ for $8 \mathrm{~h}$ at $100^{\circ} \mathrm{C}$. The solution was neutralised $\left(\mathrm{BaCO}_{3}\right)$, and the mixture containing partially $O$-methylated aldoses reduced with $\mathrm{NaBD}_{4}(5 \mathrm{mg})$ for $4 \mathrm{~h}$ at room temperature. The solution was neutralised with $50 \mu$ l glacial HOAc, dried under reduced pressure, and co-distilled with $100 \mu \mathrm{l}$ of $\mathrm{MeOH}$ at $50^{\circ} \mathrm{C}$, this step being repeated thrice. The product was acetylated with $\mathrm{Ac}_{2} \mathrm{O}$-pyridine $(500 \mu \mathrm{l} ; 1: 1, \mathrm{v} / \mathrm{v})$ overnight at room temperature. The PMAAs were extracted with $\mathrm{CHCl}_{3}$ and washed with $2 \%$ aq. $\mathrm{CuSO}_{4}$ and the organic layer containing PMAAs dried at room temperature, and the residue dissolved in acetone before GC-MS analysis.

\section{GC-MS}

Each PMAA mixture was dissolved in acetone and examined by GC-MS at a range from $m / z, 80$ to 220 , using a Varian GC, Model 3300 coupled to a Finnigan MS with ion trap detector (model ITD 800). The PMAA was applied to an OV-225 fused silica capillary column (Quadrex $-30 \mathrm{~m} \times 0.25 \mathrm{~mm}$ i.d.), with $\mathrm{He}$ as carrier gas. Conditions: electron impact at $70 \mathrm{eV}$; injector temp.: $250^{\circ} \mathrm{C}$; initial temp.: $50^{\circ} \mathrm{C}$ 


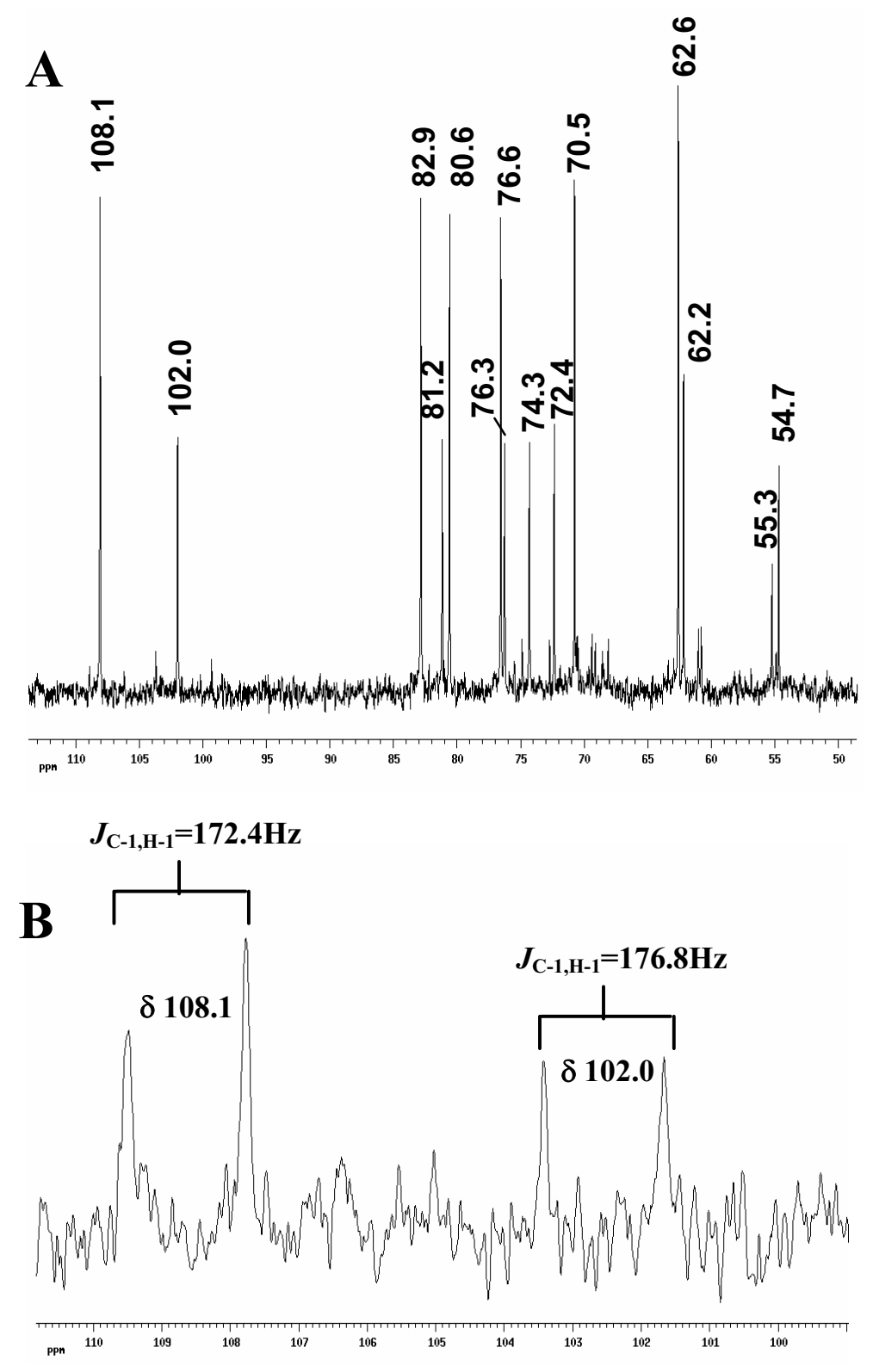

Fig. $1-{ }^{13} \mathrm{C}$ NMR spectrum of methyl $\alpha \beta$-galactofuranoside product (A) and its ${ }^{13} \mathrm{C} /{ }^{1} \mathrm{H}$-coupled anomeric region (B).

(1 min); temp. program: $40^{\circ} \mathrm{C} \mathrm{min}^{-1}$ to $220^{\circ} \mathrm{C}$, maintained for $25 \mathrm{~min}$.

\section{RESULTS AND DISCUSSION}

Arabinose and galactose were each converted to mixtures of methyl glycofuranosides using $\mathrm{MeOH}$ containing traces of $\mathrm{H}_{2} \mathrm{SO}_{4} 25^{\circ} \mathrm{C}$. The acid was removed by neutralisation with pryridine, followed by acetylation and deacetylation, ${ }^{13} \mathrm{C}$-NMR examination of the $\mathrm{Me} \alpha \beta$-Gal product at $30^{\circ} \mathrm{C}$ in $\mathrm{D}_{2} \mathrm{O}$ showed that they had furanosyl rings, as two typical low field signals at $\delta 108.1$ and 102.0 (Fig. 1A) were present (Gorin and Mazurek 1975) in a ratio of $\sim 1.95$ : 1. Its ${ }^{13} \mathrm{C},{ }^{1} \mathrm{H}$-coupled spectrum contained C-1 doublets centred at $\delta 108.1$ with $J=172.4 \mathrm{~Hz}$ ) from $\mathrm{Me} \beta-\mathrm{Gal} f$, whereas that centred at $\delta 102.0$ had $J=176.8 \mathrm{~Hz}$ (Fig. 1B). These values differed from those of a standard mixture of Me $\beta$-Gal $p$ of Me $\alpha$-Gal $p$, which gave respective signals at $\delta 103.5$ (Fig. 2A), $J=162.1 \mathrm{~Hz}$ (Fig. 2B) and $\delta 99.1$ for Me 


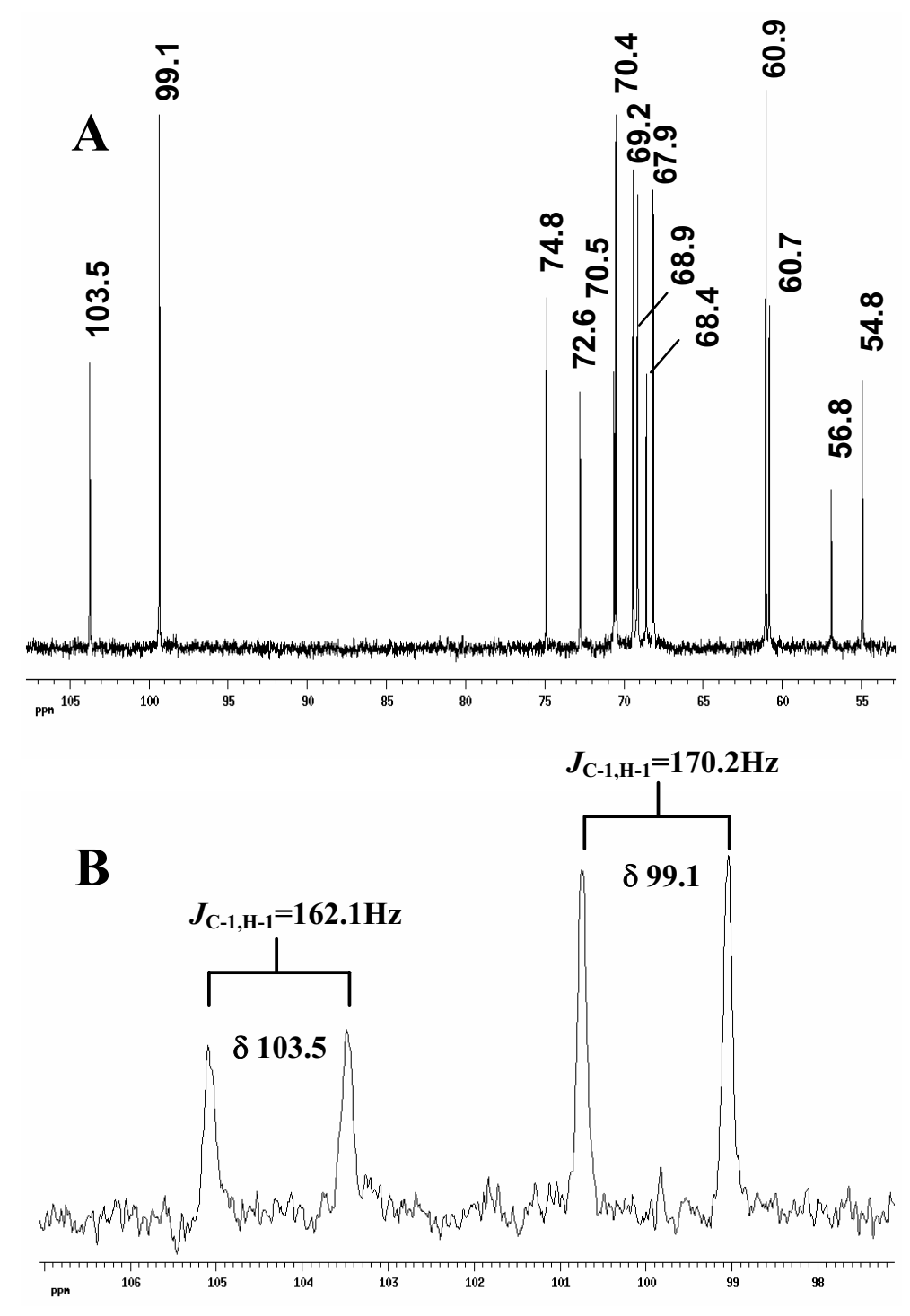

Fig. $2-{ }^{13} \mathrm{C}$ NMR spectrum of mixed methyl $\alpha$ - and methyl- $\beta$-galactopyranosides (A) and their ${ }^{13} \mathrm{C} /{ }^{1} \mathrm{H}$-coupled anomeric region (B).

$\beta$-Gal $p$ (Fig. 2A) and $J=170.2 \mathrm{~Hz}$ (Fig. 2B) for $\operatorname{Me} \alpha-\operatorname{Gal} p$. The $J$ values are consistent with those of Chambat et al. (1978), who found C-1 of Me $\beta$-Gal $f$ to have $172.5 \mathrm{~Hz}$ and $\mathrm{C}-1$ of $\mathrm{Me} \alpha$-Gal $f$ to have $\sim 175 \mathrm{~Hz}$ and Perlin and Casu (1969), who reported $169 \mathrm{~Hz}$ for $\alpha$-Glc $p$ and $160 \mathrm{~Hz}$ for $\beta$-Glc $p$.

Using a similar procedure, the decoupled and coupled ${ }^{13} \mathrm{C}$-NMR spectra of the methyl glycosidic mixture formed from arabinose contained C-1 signals for Me $\alpha$-Ara $f$ and Me $\beta$-Ara $f$ respectively at $\delta 108.7$ (Fig. 3A) and $J=173.1 \mathrm{~Hz}$ (Fig. 3B) and 102.6 (Fig. 3A) and $J=173.1 \mathrm{~Hz}$ (Fig. 3B) in a ratio of $\sim 1.5: 1$ (Fig. 3).

When the Me $\alpha \beta$-Ara $f$ mixture was treated with an excess of sodium periodate over a short period of time, the product after removal of dialdehyde with resin only gave the signals of $\operatorname{Me} \alpha$-Ara $f$ at $\delta$ 108.7 (C-1), 84.2 (C-4), 81.1 (C-2), 76.9 (C-3), 61.7 (C-5), and 55.6 $\mathrm{OCH}_{3}$, showing that the $\mathrm{Me} \beta$-Ara $f$ was preferentially oxidised.

Methylation of the methyl arabinofuranosides and galactofuranosides with the Purdie reagent over a period of time gave rise to PMGs with progressive increase in their degree of $O$-methylation. It 


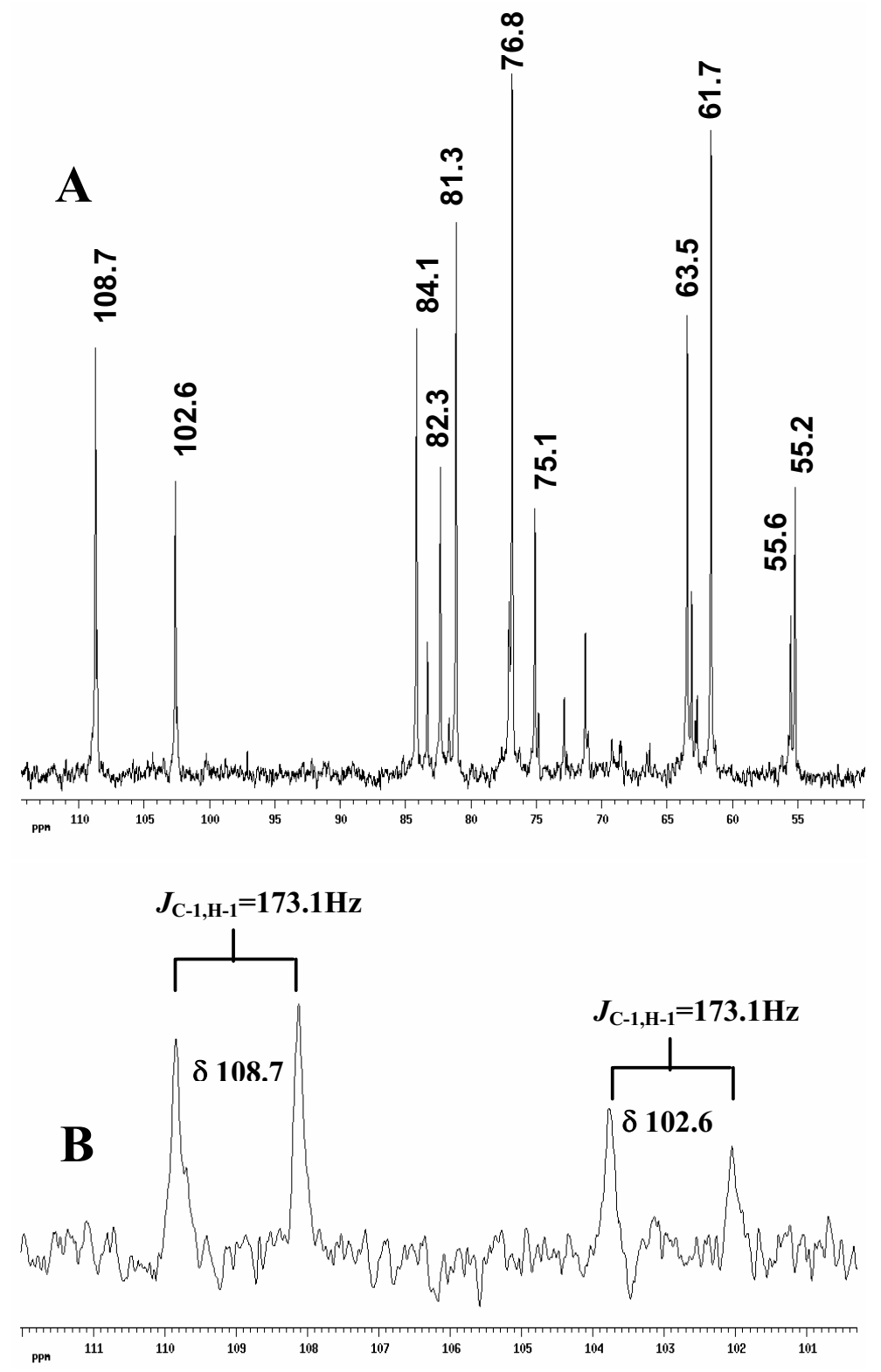

Fig. $3-{ }^{13} \mathrm{C}$ NMR spectrum of methyl $\alpha \beta$-arabinofuranoside product (A) and its ${ }^{13} \mathrm{C} /{ }^{1} \mathrm{H}$-coupled anomeric region (B).

was found using TLC that after 1 hour $\operatorname{Me} \alpha \beta$ Ara $f$ gave rise mainly to mono- $O-\left(R_{f} 0.31-0.50\right)$ and di- $O$-methyl derivatives $\left(R_{f} 0.52-0.62\right)$ and after two hours the tri- $O$-methyl derivative $\left(R_{f} 0.75\right)$ was formed. The derivatives of Me $\alpha \beta$-Gal $f$ were mainly mono- $O$ - $\left(R_{f} 0.31-0.50\right)$ and di- $O$-methyl $\left(R_{f}\right.$ 0.52-0.62) after 1 hour and tri- $O$-methyl $\left(R_{f}\right.$ $0.64)$ and tetra- $O$-methyl $\left(R_{f} 0.75\right)$ after two hours. The Purdie methylation has the advantage of being easier to handle than those of Kuhn et al. (1955) and
Doares et al. (1991), since TLC examination could be carried out by directly spotting the reaction mixture at intervals of 30 minutes on to TLC plates, without prior removal of non-volatile solvents.

Each product obtained after 1 and 2 hours reaction time was converted to mixtures of PMAAs via successive hydrolysis, reduction with $\mathrm{NaBD}_{4}$, and acetylation. The resulting PMAA mixtures contained the necessary components for analysis of all, with one exception, arabinofuranose- and galacto- 
TABLE I

Partially $O$-methylated alditol acetates obtained following Purdie methylation synthesis after $2 \mathrm{~h}$ reaction with methyl furanosides of Ara and Gal.

\begin{tabular}{|c|c|c|c|}
\hline OMe alditol acetate & $R_{t}$ & From $\alpha \beta$-derivative ${ }^{\mathrm{a}}$ & From $\alpha$-Ara $f$ \\
\hline $2,3,5-\mathrm{Me}_{3} \mathrm{Ara}$ & 7.3 & 1.0 & 1.7 \\
\hline $3,5-\mathrm{Me}_{2} \mathrm{Ara}$ & 8.3 & 0.7 & 1.3 \\
\hline 2,5-Me ${ }_{2} \mathrm{Ara}$ & 8.5 & 11.1 & 18.0 \\
\hline 2,3-Me $\mathrm{Me}_{2} \mathrm{Ara}$ & 9.1 & 25.0 & 24.5 \\
\hline 5-MeAra & 9.5 & 3.4 & 7.3 \\
\hline 2-MeAra & 10.5 & 46.1 & 39.5 \\
\hline 3-MeAra & 11.1 & 12.0 & 7.7 \\
\hline $2,3,5,6-\mathrm{Me}_{4} \mathrm{Gal}$ & 8.3 & 1.4 & - \\
\hline 2,5,6- $\mathrm{Me}_{3} \mathrm{Gal}$ & 10.5 & 5.6 & - \\
\hline $2,3,5-\mathrm{Me}_{3} \mathrm{Gal}$ & 12.1 & 1.7 & - \\
\hline $2,3,6-\mathrm{Me}_{3} \mathrm{Gal}$ & 11.1 & 5.9 & - \\
\hline $3,5,6-\mathrm{Me}_{3} \mathrm{Gal}$ & 11.1 & 1.4 & - \\
\hline $2,3-\mathrm{Me}_{2} \mathrm{Gal}$ & 15.2 & 10.2 & - \\
\hline $2,5-\mathrm{Me}_{2} \mathrm{Gal}$ & 15.0 & 1.3 & - \\
\hline 2,6- $\mathrm{Me}_{2} \mathrm{Gal}$ & 12.6 & 32.0 & - \\
\hline $3,5-\mathrm{Me}_{2} \mathrm{Gal}$ & 15.5 & 2.1 & - \\
\hline $3,6-\mathrm{Me}_{2} \mathrm{Gal}$ & 13.5 & 6.0 & - \\
\hline${ }^{\mathrm{b}} 5,6-\mathrm{Me}_{2} \mathrm{Gal}$ & 12.0 & 5.3 & - \\
\hline 2-MeGal & 17.4 & 17.8 & - \\
\hline 3-MeGal & 20.1 & 8.7 & - \\
\hline c5-MeGal & 17.4 & 0 & - \\
\hline 6-MeGal & 16.5 & 0.4 & - \\
\hline
\end{tabular}

${ }^{\mathrm{a}}$ Mixture of $\alpha \beta$-anomers obtained on methyl glycosidation; ${ }^{\mathrm{b}} 5,6-\mathrm{Me}_{2} \mathrm{Gal}$ eluted before 2,3,5$\mathrm{Me}_{3} \mathrm{Gal} f$; ${ }^{\mathrm{c}}$ Indentifiable in methylation analysis mixtures with identical $R_{t}$ as that of 2-MeGal, but with a key ion at $m / z 117$ instead of 118 .

furanose-containing structures by GC-MS, by virtue of their typical $R_{t} \mathrm{~s}$ and e.i. breakdown patterns (Table I and Fig. 4). The e.i. profile of each PMAA was recorded over a range of $m / z 80$ to 220 and its key ions are represented in Figure 4. Although some of the yields were rather low, the required derivatives of 3,5,6- $\mathrm{Me}_{3} \mathrm{Gal}(1.4 \%), 2,5,6-\mathrm{Me}_{3} \mathrm{Gal}(5.6 \%)$, 2,5- $\mathrm{Me}_{2} \mathrm{Gal}(1.3 \%), 3,5-\mathrm{Me}_{2} \mathrm{Gal}(2.1 \%)$, and 5,6$\mathrm{Me}_{2} \mathrm{Gal}(5.3 \%)$ were obtained, being were detectable on GC-MS. One exception in the rapid synthe- sis was the acetate of 5-O-methylgalactitol. However, its presence in any methylation analysis mixture could be detected since it has an $R_{t}$ identical to that of the 2- $O$-methyl derivative and would give a similar EI-MS, but with a key ion at $m / z 117$ instead of 118 (Figure 4, B12).

For determination of the relative reactivities of hydroxyl groups in the Me $\alpha \beta$-Gal $f$ mixture, attention was paid to the formation of mono- $O$ methyl derivatives, since further methylation of - 

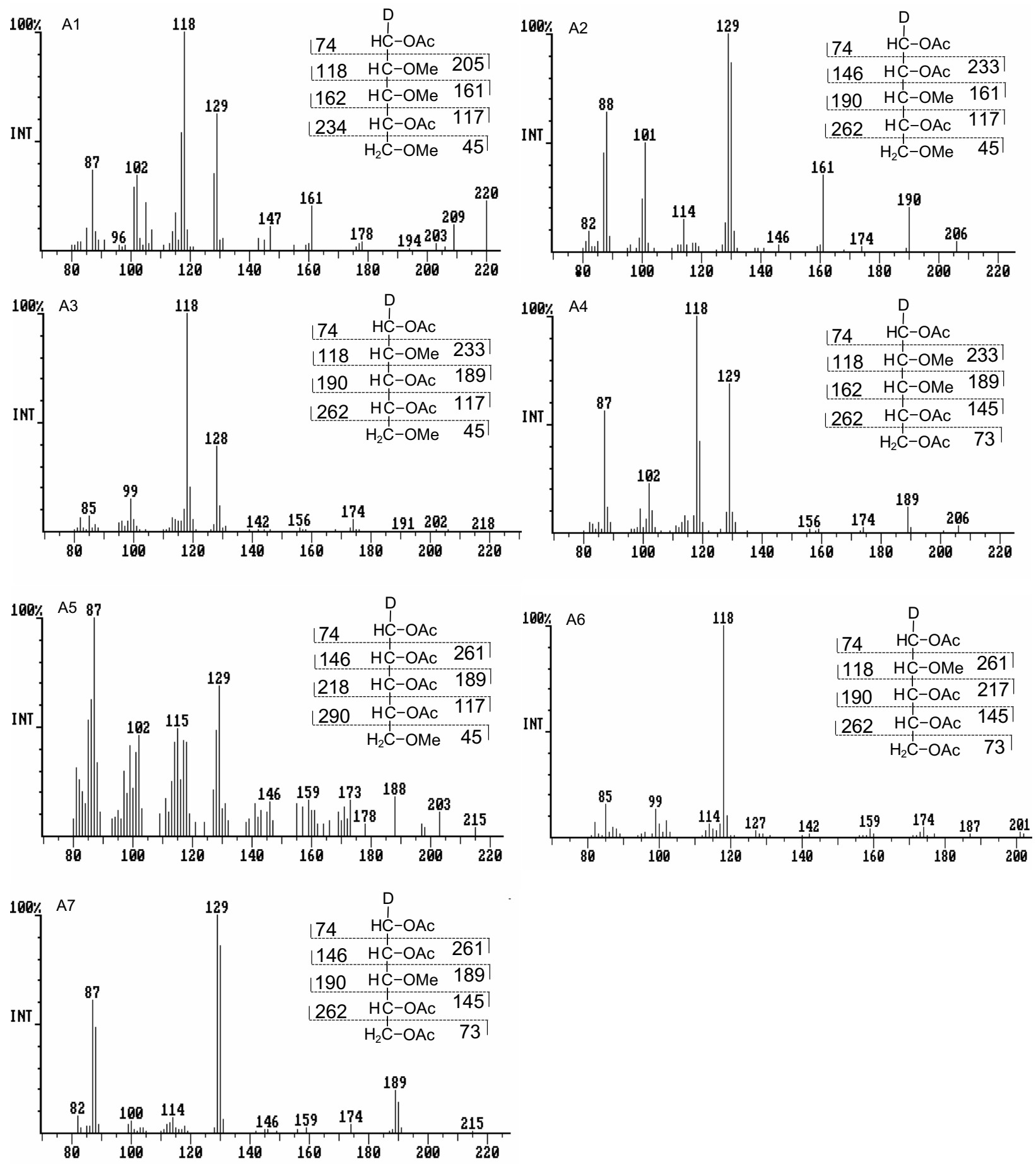

(4a)

Fig. 4 - EI-MS patterns at $m / z 80$ to 220 of PMAA standards deuterated at C-1: 2,3,5-Me ${ }_{3} \operatorname{Ara}(\mathrm{A} 1), 3,5-\mathrm{Me}_{2} \mathrm{Ara}(\mathrm{A} 2), 2,5-\mathrm{Me}_{2} \mathrm{Ara}$ (A3), 2,3-Me 2 Ara (A4), 5-MeAra (A5), 2-MeAra (A6), 3-MeAra (A7), 2,3,5,6-Me 4 Gal (B1), 2,5,6-Me 3 Gal (B2), 2,3,5-Me 3 Gal (B3),

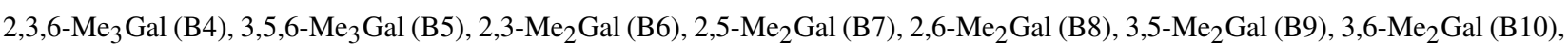
5,6-Me $2 \mathrm{Gal}$ (B11), 2-MeGal (B12), 3-MeGal (B13), and 6-MeGal (B14). 

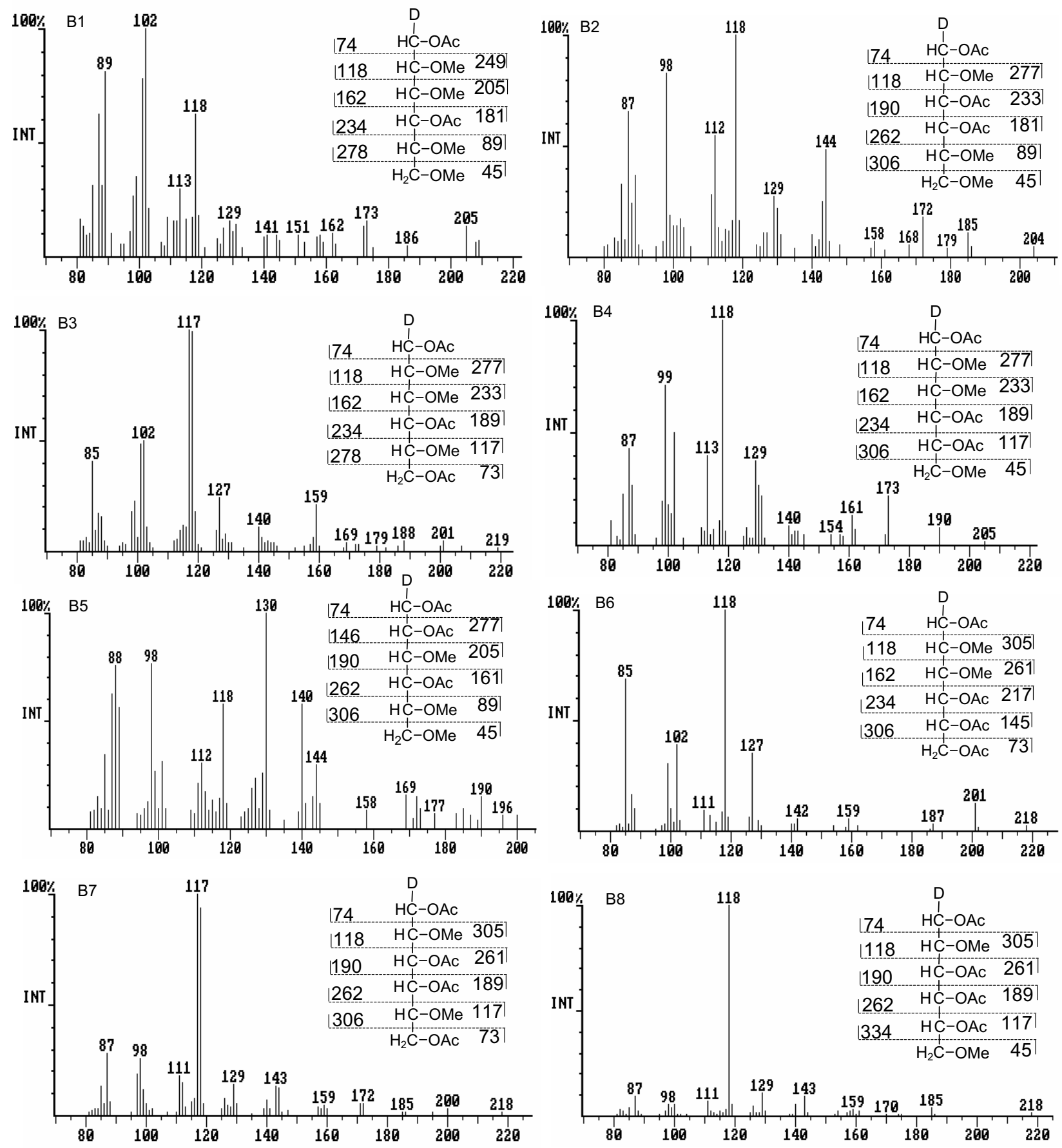

(4b) 

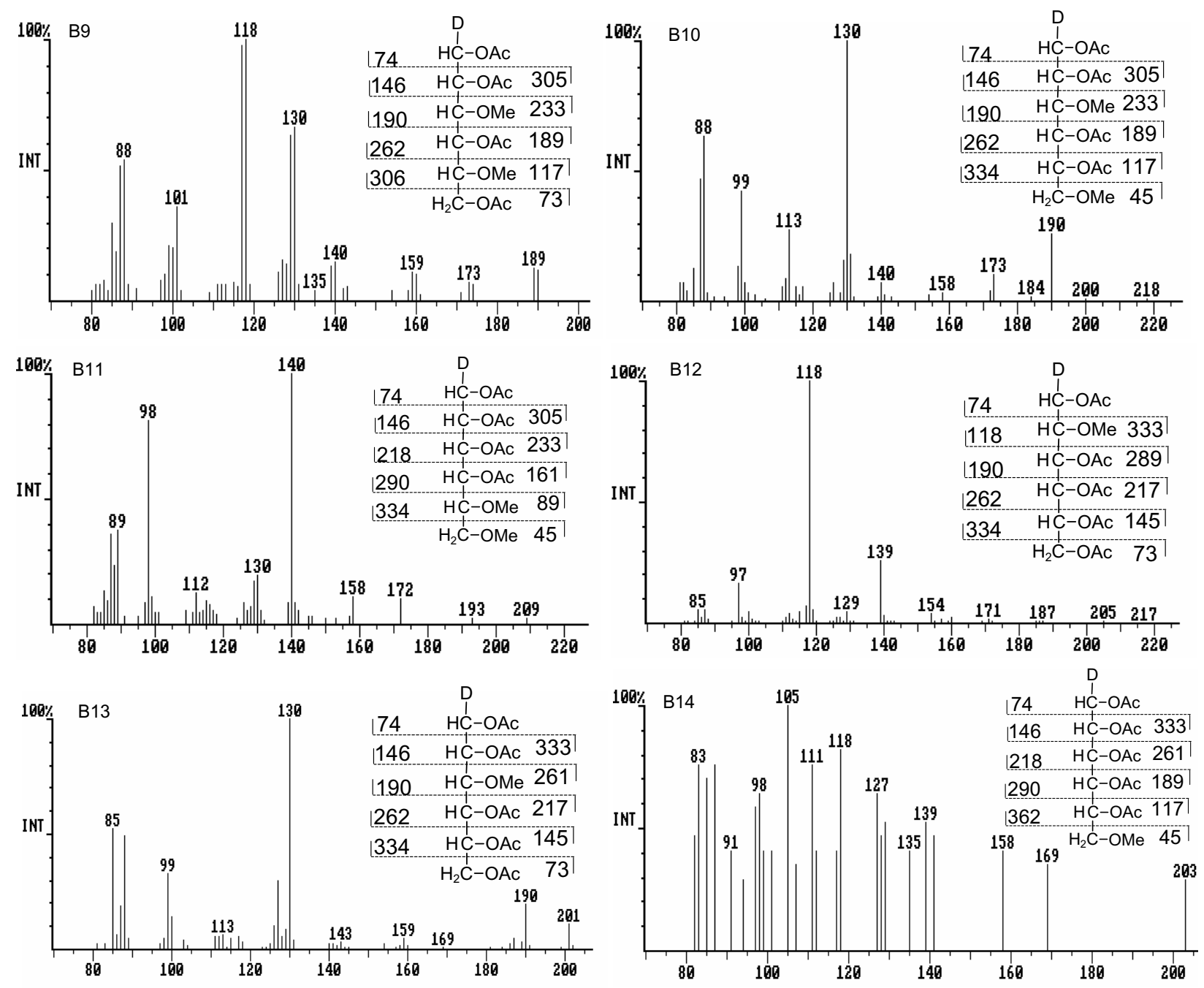

(4c)

$\mathrm{CHOH}$ groups vicinal to those of $-\mathrm{CHOCH}_{3}$ would be more rapid. Consequently we can interpret (Table I) and that in the case of the $\alpha \beta$-mixture of Me-Gal $f$ the order is HO-2 $>$ HO-3 $>$ HO-6 $>$ HO-5, which differs from those of Me $\alpha$ - and $\beta$-Gal $p$, which is HO-3 > HO-2 > HO-4 > HO-6 (Sassaki et al. 2005).

The relative reactivities for the $\operatorname{Me} \alpha \beta$-Ara $f$ mixture was HO-2 > HO-3 > HO-5, and for Me $\alpha$ Ara $f$, they were not markedly different, with HO-2 $>$ HO-3 $\geq$ HO-5 (Table I).

\section{ACKNOWLEDGMENTS}

The authors wish to thank the Brazilian agencies Financiadora de Estudos e Projetos (FINEP) and Conselho Nacional de Desenvolvimento Científico e
Tecnológico (CNPq), and Fundação Araucária, State of Paraná for financial support.

\section{RESUMO}

Arabinose e galactose foram tratadas com metanol anidro contendo quantidades catalíticas de $\mathrm{H}_{2} \mathrm{SO}_{4}$ e $\mathrm{HCl}$ a $25^{\circ} \mathrm{C}$ visando a formação de suas respectivas misturas de alphae beta-metil- glicofuranose, as quais foram confirmadas por ressonância magnética nuclear (RMN) unidimensional e bidimensional. A mistura de alpha, beta-Me-Ara $f$ foi oxidada com $\mathrm{NaIO}_{4}$, dando origem somente à Mealpha-Ara $f$, mostrando que o isômero beta é oxidado preferencialmente. Cada derivado furanosídico foi metilado pelo reagente de Purdie $\left(\mathrm{Ag}_{2} \mathrm{O} / \mathrm{MeI}\right)$ a $25^{\circ} \mathrm{C}$, dando origem a misturas de metil glicofuranosídeos parcial- 
mente metilados (Me-GFP), os quais tiveram seus respectivos graus de metilação monitorados por cromatografia em camada delgada (CCD), que variaram inicialmente em altos rendimentos de derivados mono metilados de Me-GFP a derivados com alto grau de metilação. Os produtos da reação foram convertidos a derivados alditol acetato parcialmente metilados (AAPM), após hidrólise, seguida de redução com $\mathrm{NaBD}_{4}$ e posterior acetilação. Os derivados obtidos podem ser utilizados como padrões de AAPM em CG-EM para auxiliar na análise de metilação de carboidratos complexos que possam conter unidades de arabinofuranose e galactofuranose. Os derivados AAPM de 6-MeGal, 5,6- $\mathrm{Me}_{2} \mathrm{Gal}$, 2,5- $\mathrm{Me}_{2} \mathrm{Gal}$, 2,5,6- $\mathrm{Me}_{3} \mathrm{Gal}$, 3,5,6- $\mathrm{Me}_{3} \mathrm{Gal}$, 5- $\mathrm{Me}_{2} \mathrm{Ara}$, 2,5- $\mathrm{Me}_{2} \mathrm{Ara}$ e 3,5- $\mathrm{Me}_{2} \mathrm{Ara}$ mostraram espectros de eletroimpacto e tempos de retenção de maior interesse pois são de difícil síntese. A avaliação da reatividades dos grupos hidroxílicos nesta metilação mostrou que a mistura de alpha, beta-Me-Gal $f$ reage preferencialmente em HO-2 > HO-3 > HO- $6>\mathrm{HO}-$ 5 , a mistura de alpha, beta-Me-Ara $f$ em HO-2 $>$ HO-3 $>$ HO-5, alpha-Me-Ara $f$ em HO-2 > HO-3 $\geq$ HO-5.

Palavras-chave: alditol acetatos parcialmente metilados, padrões p/ CG-EM, metilação de Purdie, reatividade grupos hidroxílicos, RMN.

\section{REFERENCES}

BArreto-Bergter E ANd Gorin PAJ. 1983. Structural chemistry of polysaccharides from fungi and lichens. Adv Carbohydr Chem Biochem 41: 67-103.

Carpita NC And Shea EM. 1989. Linkage structure of carbohydrates by gas chromatography-mass spectrometry (GC-MS) of partially methylated alditol acetates: analysis of carbohydrates by GLC and MS. In Analysis of Carbohydrates by GLC and MS; Biermann CJ.; McGinnis GD., Eds., CRC Press, Inc., Boca Raton: 157-216.

Chambat G, Joseleau J-P, Lapeyre M and Lefebvre A. 1978. Presence of galactofuranose in the capsular polysaccharide of Klebsiella serotype K-41: Synthesis of 5,6-di- $O$-methyl-D-galactofuranose. Carbohydr Res 63: 323-326.

Ciucanu I And KereK F. 1984. A simple and rapid method for the permethylation of carbohydrates. Carbohydr Res 131: 209-217.
Doares AS, Albersheim P And Darvill AG. 1991. An improved method for the preparation of standards for glycosyl-linkage analysis of complex carbohydrates. Carbohydr Res 210: 1021-1037.

Elkin YN, Shulga NI, VAKorina TI And Dzizenko AK. 1975. Partial methylation of methyl glycoside: a source of samples for analysis of carbohydratecontaining compounds. Anal Biochem 68: 9-16.

Fournet B And Montreuil J. 1973. Procédé d'ídentification et de prépration par chromatographie em phase gazeuse des éthers di-, tri-, et tetramethyliques de l' $\alpha$ méthyl-D-mannoside. J Chromatogr 75: 29-37.

Fournet B, Leroy Y, Montreuil J AND Mayer H. 1974. Analytical and preparative gas-liquid chromatography of methyl $\alpha$-mannoside monoethyl ethers. J Chromatogr 92: 185-190.

Fournet B, Dhalluin J-M, Leroy Y AND Montreuil J. 1978. Analytical and preparative gas-liquid chromatography of the fifteen methyl ethers of methyl $\alpha$-D-galactopyranosides. J Chromatogr 158: 91-99.

Gorin PAJ AND MAZUREK M. 1975. Further studies on the assignment of signals in ${ }^{13} \mathrm{C}$ magnetic resonance spectra of aldoses and derived methyl glycosides. Can J Chem 53: 1212-1223.

HAKOMORI S. 1964. A rapid permethylation of glycolipid, and polysaccharide catalyzed by methylsulfinyl carbanion in dimethyl sulfoxide. J Biochem 55: 205-207.

Handa N and Montgomery R. 1969. Partial methylation of methyl $\alpha$-D-mannopyranoside. Preparation and distribution of mono-, di-, and trimethyl ethers of D-mannose. Carbohydr Res 11: 467-484.

HawORTH WN. 1915. A new method of preparing alkylated sugars. J Chem Soc 107: 8-16.

JANSSON P-E, KenNe L, LiEdGREN H, LindBERG B AND LÖNNGREN J. 1970. A practical guide to the methylation analysis of carbohydrates. J Chem Commun, Univ of Stockholm, 8: 1-76.

Jones C, Todeschini AR, Agrellos AO, Previato JO and Mendonça-Previato L. 2004. Heterogeneity in the biosynthesis of mucin $O$-glycans from Trypanosoma cruzi Tulahuen strain with the expression of novel galactofuranosyl-containing oligosaccharides. Biochemistry 43: 11889-11897.

Kuhn R, Trischmann H and Löw I. 1955. Zur Permethylierung von Zuckern und Glykosiden. Angew Chem 67: 32. 
Levery SB, Toledo MS, Straus AH and Takahashi HK. 1998. Structure elucidation of sphingolipids from the mycopathogen Paracoccidioides brasiliensis: An immunodominant $\beta$-galactofuranose residue is carried by a novel glycosylinositol phosphorylceramide antigen. Biochemistry 37: 8764-8775.

Lomax JA And Conchie J. 1982. Separation of methylated alditol acetates by glass capillary gas chromatography and their identification by computer. J Chromatogr 236: 385-394.

Perlin AS and Casu B. 1969. Carbon-13 and proton magnetic resonance spectra of D-glucose- ${ }^{13} \mathrm{C}$. Tetrahedron Letters: 2921-2924.

Purdie T And Irvine JC. 1903. The alkylation of sugars. J Chem Soc 83: 1021-1037.

Sassaki GL, Ferreira JC, Glienke-Blanco C, Torri G, DE Toni F, Gorin PAJ And Iacomini M. 2002. Pustulan and branched $\beta$-galactofuranan from the phytopathogenic fungus Guignardia citricarpa, excreted from media containing glucose and sucrose. Carbohydr Polym 48: 385-389.
Sassaki GL, Gorin PAJ, Souza LM, Czelusniak PA AND IACOMINi M. 2005. Rapid synthesis of partially $O$-methylated alditol acetate standards for GC-MS: Some relative activities of hydroxyl groups of methyl glycopyranosides on Purdie methylation. Carbohydr Res 340: 731-739.

SKIPISKI VP. 1975. Thin layer chromatography of neutral glycolipids. Methods Enzymol 35: 396-425.

Suzuki E, Toledo MS, Takahashi HK and Straus AH. 1997. A monoclonal antibody directed to terminal residue of $\beta$-galactofuranose of a glycolipid from Paracoccidioides brasiliensis: cross-reactivity with Leishmania major and Trypanosoma cruzi. Glycobiol 7: 463-468.

Svetek J, Yadav MP and Nothnagel EA. 1999. Presence of a glycosylphosphatidylinositol lipid anchor on rose arabinogalactan proteins. J Biol Chem 274: 14724-14733. 